\title{
Who or what is to blame for the power paradox in society?
}

\author{
Elma M Cornelius \\ North-West University \\ Potchefstroom, South Africa \\ Elma.Cornelius@nwu.ac.za
}

\begin{abstract}
We vote for people who seem to be promising good leaders and somehow, they turn out to be terrible leaders. This tendency Keltner (2007) calls the "power paradox". The moment people gain power or success or wealth, their characteristics of empathy, collaboration, open mindedness, fairness, and generosity vanish into thin air and we have to deal with impulsive and self-serving leaders. The experience of power thus damages leaders' social intelligence. The author of this article asks: who or what is to be blamed for this power paradox? Keltner suggests that we need people with a focus on others, who have empathy, a giving personality, gratitude, and unifying stories. The author suggests that spiritual intelligence can fix the power paradox in society as she shows that Keltner's principles for enduring power are no different from the spiritual gifts explained in the Bible of Christianity. Spiritual intelligence is offered as the solution to the power paradox.
\end{abstract}

Keywords

power paradox; power abuse; enduring power; spiritual intelligence; fruits of the spirit

\section{Introduction}

Keltner (2016:23) says power is about making a difference in the world by altering the states of others. It is part of every relationship and interaction; hence it is found in everyday actions. No relationship is thus free of power dynamics. The experience of power propels the individual forward in one of two directions: toward the abuse of power and impulsive and unethical actions, or toward benevolent behaviour that advances the greater good (Keltner 2016:70-71). 
Societies suffer because of power abuse. People take power into their own hands and destroy their societies by murdering, stealing, hijacking, raping, lying, cheating, being corrupt, etc. In some cases, it happens because of an abuse of given power, in other cases, power is simply grabbed without permission. The abuses of power occur in every corner of our social life and Keltner (2016:9) gives the following as examples of problems caused by the abuse of power: greedy eating, swearing, rudeness, lying, sexual affairs, sexual violence, racial violence, unethical behaviour, and arrogant driving.

The abuse of power, Keltner (2016) says, is to be blamed on the "power paradox"; the seductions of power cause us to lose the very skills that enabled us to gain power in the first place (Keltner 2007:7). We rise in power and make a difference in the world due to what is best about human nature, but we fall from power due to what is worst (Keltner 2007:1-2). This power paradox has the following implication: We gain power and the capacity for influence through social practices that advance the interests of others, such as empathy, collaboration, open-mindedness, fairness, and generosity. And yet, once we gain power, success, or wealth, those very practices vanish, leaving us vulnerable to impulsive, self-serving actions, and empathy deficits that set in motion our fall (Keltner 18 May 2016). The experience of power thus damages leaders' social intelligence. Keltner (2007) warns against the corruptive influence of power and its ability to distort the way we see ourselves and treat others.

What is the effect of the abuse of power and the power paradox on society? It leaves our societies powerless and this powerlessness is, according to Keltner (2007:10), the greatest threat facing our societies today outside of climate change. Poverty, inequality, racism, gender bias - a few consequences of power abuse - all contribute to societies becoming powerless.

Who is to be blamed for this power paradox? What can be done to limit or exclude the power paradox in order to save society?

In 1887, Baron John Acton wrote a letter ${ }^{1}$ to an Anglican bishop in which he stated: "power tends to corrupt, and absolute power corrupts absolutely" (Figgis \& Laurence 1907). More than a hundred years later, scientists claim

1 The letter was published in Historical Essays and Studies, edited by J. N. Figgis and R. V. Laurence (London: Macmillan, 1907). 
that this saying is biologically true. Psychologist Ian Robertson (2012) wrote on how power affects the brain. Power has an effect on the same reward circuits in the brain as cocaine. His research shows that baboons on the lower spectrum of the dominance hierarchy have lower levels of dopamine in key brain areas, but when they are "promoted" to a higher position, then dopamine rises accordingly. According to Robertson (2012), similar changes happen when people are given power. The feeling of power increases the levels of testosterone and its by-product 3-androstanediol, with the effect of increased dopamine levels. The higher dopamine levels make people smarter, because dopamine improves the functioning of the brain's frontal lobes. The effect is as strong as any drug and that is why power can become addictive like any other drug. Like too much cocaine can produce too much dopamine, leading to more negative effects such as arrogance and impatience, too much power can move people to power abuse and aggression and self-centeredness. Too much dopamine can thus lead to the power paradox. Keltner (2016:40) explains that dopamine and the feelings of power are at the heart of addictions, which lead to impulsive, unethical action, and delusional thought. The moment human beings rise to power, the very experience of having power and privilege leads them to behave at their worst, like impulsive, out-of-control sociopaths (Keltner 2016:1-2).

Does this mean that scientists can perhaps try to develop a medicine to decrease dopamine levels in leaders in order to save society from power abuse? When I read Keltner's (2016) definitions and principles of power, the question of whether or not the power paradox is really to be blamed on dopamine, arose. This will be explained in the next subsection.

\section{What we need to solve problems is "enduring power"}

This "power paradox" Keltner is referring to implies that something causes leaders in power positions to abuse their power. And this abuse of power is costly in so many ways. It leads to empathy deficits and diminished moral sentiments, self-serving impulsivity, incivility and disrespect, and narratives of exceptionalism (Keltner 2007:101).

Keltner (2007:71) explains that when individuals use their power to advance the greater good, they and the people whom they empower will be happier, 
healthier, and more productive. This is what he refers to as "enduring power". Enduring power comes from a focus on others, empathy, giving, expressing gratitude, and from telling stories that unite Kelter (2007:6973). When we lose sight of these principles of enduring power, we are more likely to eat impulsively, have sexual affairs, violate the rules of the road, to lie and cheat, shoplift, and communicate in rude, profane and disrespectful ways (Keltner 2007:99-100).

What we thus need to save our societies is an enduring power that will come from a focus on others, empathy, a giving personality, a person willing to express gratitude and people telling stories to unite people. We thus need something, not necessarily decreasing dopamine levels in people in power positions but decreasing selfish attitudes. This is why the author proposes spiritual intelligence to solve this problem of the power paradox and power abuse.

\section{Spiritual intelligence as a possible cure for a sick society}

For a moment, while reading Keltner's book (2007), the author assumed Keltner would acknowledge the importance of spiritual intelligence. Keltner (2007:69) does acknowledge that "the belief that a sacred, living force propels us to make a difference in the world is universal to humanity". Keltner (2007:69) further states we might call this sacred living force a purpose or mission or calling, and then opted for the word "power." The author would opt for "spiritual power" as the spiritual power of a god being served and followed, because of a person's spiritual intelligence, can indeed propel us to make a positive difference in this world. This spiritual power can indeed bring us to an enduring power that will benefit this world.

Spiritual intelligence is an intelligence of knowing that there must be a spiritual power (see Cornelius, 2014 and Buzan 2001). If people recognise the importance of orienting their lives to something non-material that is beyond and larger than themselves, of depending on a higher power (Martin \& Carlson 1988:59), they can be considered to be spiritually intelligent. This spiritual intelligence can bring such people to searching for, finding and living according to a religion - a system providing the resources for living a good life; for becoming leaders with enduring power. 
Thomas Aquinas (The Summa Theologica II-II q.1-170) differentiates between the gifts and the fruits of the Spirit. He claims that humankind is moved by reason in internal and external actions. This means that when people become spiritually intelligent (formulation of the author), when they are willing to be moved by God (Thomas Aquinas, The Summa Theologica II-II q.1-170), one will be able to see the gifts of the Spirit in them, namely an understanding, knowledge, and wisdom. The fruits of the Spirit are then the products of one's awareness of God (spiritual intelligence), and of one's willingness to be moved by God (Thomas Aquinas, The Summa Theologica I-II q.70 a.1).

The question is, are the principles of enduring power, as discussed by Keltner (2016) also the fruits of the Spirit? In other words, will spiritual intelligence and a resulting willingness to follow the power one became aware of, lead one to enduring power? Can spiritual intelligence prevent power abuse and save society?

\section{Are the principles of enduring power the fruits of the spirit?}

Cornelius (2007:596) has already showed how the Christian Bible offers many guidelines for a spiritually intelligent person and that Galatians 5:16-25 can play an important role to move a person to live a Spirit-filled life in order to escape the sinful nature and gain freedom through the Spirit (Cornelius 2007:599).

The question to be answered in this article, is whether Keltner's principles for enduring power can be seen as the typical fruits of the Spirit as found in the Bible.

\subsection{Focus on others}

People who enjoy power are more likely to violate the rules of the road, to lie and cheat, to steal, and to communicate in rude, profane, and disrespectful ways. The experience of power absolutely overwhelms them and that is when their attention shifts from their focus on others to their own interests and desires. When one's attention is directed to oneself, one loses focus on other people. Others' goals, safety, desires, feelings, and needs become no 
longer relevant. An absence of a focus on others is the ultimate reason for power abuse.

With a spiritual intelligence, one's focus is already no longer on the self, but mainly on a power beyond oneself. If spiritual intelligence can persuade a person to find a religion where he/she can get to know this power beyond, and begin to live a life guided by God, the danger of the power paradox can indeed be limited.

Muslims believe with conviction that there is one supreme creator, an infinite, eternal power who can do all things and knows all things. This god, called Allah (the Arabic term for God) by Muslims, holds all human beings accountable for their deeds (see Beverley, 2001:1). Cole (1991:114) describes Muslims as people who have become aware of the reality of the existence of God, and have committed themselves to submission of God's will as expressed in the revelations given to the Prophet Muhammad. Once this spiritual awareness - spiritual intelligence - has come into persons and once they have found their god, life is never the same again. They become believers and it is the beginning of a long spiritual journey. Muslims believe that all human life is sacred and therefore power abuse in the form of the oppression of women, children, old people, the sick or the wounded, or indeed, any person is not permissible (see Cole 1991:116).

In Buddhism, Siddharta Gautama - the Buddha (meaning the "enlightened one") - became enlightened and then taught others how to attain the state of enlightenment. He left behind a major religion, which can provide a spiritually intelligent person with a profound system for understanding life (see Cole 1991:6-7). At the heart of the Buddha's teachings in the Eightfold Path, Cole (1991:7) explains, is the idea of not causing harm or suffering to any other being. The focus is thus on others because of one's dedication to the Buddha.

Hindus worship one god under different names and appearances, both male and female (Cole, 1991:78). Their scriptures declare that every creature is a part of Brahman, the Supreme Spirit. The core of Hindu moral law is dharma (moral duty or responsibility) and this will vary from person to person according to their social class. Dharma places the individual continuously under an obligation to act as a social being, as a small part 
of a larger whole. The fact is Hindus also put limits on the behaviour of people.

In the Bible, God claims to be the ultimate power in mankind's lives (Ex 20:2) and it is forbidden to serve anyone or anything else - including oneself (Ex 20:3-4). This god's law is to love this god, and to love others like one loves oneself (Mt 22:37-40). This god wants to see the fruits of the Spirit in believers. Jesus said himself that no branch can ever bear fruit by itself, it must remain on the vine (Jn 15:4). If we do not remain in Christ, we can never bear the fruits of the spirit. These fruits are the products of God's control in our lives. Our lives need to reflect God in love, joy, peace, patience, kindness, goodness, faithfulness, gentleness, self-control, love to one's neighbour, and humbleness (see Gal 5:22-23; Eph 4:2-3; Col 3:12-15; 2 Pet 1:5-7; Rom 14:17).This focus on others, Keltner (2016:69-73) explains, comes out in empathy, a giving personality, gratitude, and telling stories to unite people.

\subsection{Empathy}

Keltner (2007:72) says enduring power comes from empathy. We need to practice empathy - focus on what others feel. Keltner (2007:74) discusses Lincoln's power as president of the United States. Lincoln's philosophical genius, Keltner says, was rooted in knowing the minds of others, in understanding what others felt. Paying careful attention to others' emotions is a way of showing respect and eliminates some of the misunderstandings and stressful conflicts that can undermine smooth and productive social interactions (Keltner 2007:75).

Empathy refers to one's capacity to feel, be aware of, and care about others' feelings, thoughts, and attitudes. Paul encourages empathy when he exhorts the Romans to rejoice with those who rejoice, to mourn with those who mourn (Rom 12:15). True empathy is to participate not only in others' happiness, but also in others' suffering.

1 John 4:21 makes it clear: whoever loves God, must also love his brother. In John 13:34 Jesus said that we must love one another as He has loved us. We should thus treat others the way Jesus treats us. Jesus loves us unconditionally. This is where kindness, goodness, and gentleness come in. If one has the love of God in him, he will have pity on those in need (1 
In 3:17). The love we need to treat others with, implies empathy, looking at others with a soft eye, caring about what they feel, think and fear, and treating them with kindness, goodness and gentleness.

Jesus is held as an example of empathy to Christians. Matthew 9:36 tells us how Jesus, when he saw the crowds, had compassion for them because they were harassed and helpless. Jesus raised a widow's son from the dead because his heart went out to her when he saw her crying (Lk 7:11-17).

Ephesians 4:32 spells it out: be kind and compassionate to one another. Colossians 3:12 commands us to clothe ourselves with compassion, kindness and gentleness. God is referred to in 2 Corinthians 1:3-5 as the Father of compassion and the God of all comfort. 1 Peter 3:8 exhort us to be sympathetic and compassionate. These spiritual gifts of compassion and kindness move people to be giving.

\subsection{A giving personality}

Keltner refers to tangible things such as food, symbolic things like money, and social things like respect (Ketlner 2007:72) to be given to others, but he also focuses on warm, friendly patterns of touch (Keltner 2007:83-86). By giving to others, we provide rewards through sharing, encouraging, sacrificing, affirming, valuing, and giving responsibilities.

1 John 3:17 reminds us that if we have the love of God in us, we will have pity on those in need. Acts 20:35 says we must help the weak, remembering the words of Jesus who said: "it is more blessed to give than to receive". Giving is part of Christian life. When a rich young man came to Jesus and asked what he must do to get eternal life, Jesus said "obey the commandments" (Mt 19:16-17). When the young man answered that he had kept all the commandments, Jesus said "sell your possessions and give it to the poor" (Mt 19:21). If we give up what is precious to us for the sake of God, we will receive a hundred times as much (Mt 19:29). Paul refers to it as the "grace of giving" (2 Cor 8:7). In 2 Corinthians 9:6-15 Paul reminds us: "Whoever sows sparingly will also reap sparingly, and whoever sows generously will also reap generously". God loves a cheerful giver, Paul says.

McConnell (25 December 2010) refers to the sayings from the Book of Acts and Mahatma Ghandi respectively: "it is more blessed to give than to receive" (Acts 20:35) and "the best way to find yourself is to lose yourself 
in the service of others" (Ghandi). According to McConnell (25 December 2010) these sayings are true because giving brings happiness as the act of giving means one appreciates and values others.

\subsection{Expressing gratitude}

Keltner (2007:87) explains that gratitude is the reverence we feel for things that are given to us - material possessions, experiences, opportunities, life conditions, and/or persons - things we did not attain through our own agency or will. When we translate this interior experience of gratitude into an outward expression of giving, we maintain enduring power, Keltner (2007:88) says.

The Bible provides many reasons for being thankful and for expressing gratitude:

- For God's goodness and enduring love (Ps 118:29);

- For God's wonderful deeds (Ps 75:1);

- For God's protection (Ps 56:13-14);

- For God's grace (1 Cor 1:4);

- For God's healing (Lk 17:16);

- Victory over sin and death (1 Cor 15:57);

- For everything (Eph 5:20).

1 Thessalonians 5:18 gives the command: "give thanks in all circumstances, for this is God's will". Giving thanks is an act of humbleness, and an act of expressing one's reliance on a power beyond oneself. In Christianity, all thanks are given to God, since all goodness, love, protection, grace, healing, victories - even though people might be involved - comes from God.

Morin (3 April 2015) lists various proven benefits of gratitude in a person's life and mentions inter alia that it improves psychological health. As gratitude reduces a multitude of toxic emotions like envy, resentment, frustration, and regret, it enhances empathy and reduces aggression. She says that people with gratitude experience more sensitivity and empathy toward others and a decreased desire to seek revenge. As gratitude also improves a person's self-esteem, it reduces social comparisons. Instead of being jealous of what other people have, grateful people rather appreciate other people's accomplishments. Understanding the psychological benefits 
of gratitude helps one to understand why gratitude will automatically limit power abuse.

\subsection{Telling stories to unite people}

Good storytelling, Keltner (2007:94-95) claims, makes for enduring power as it enhances the interests of others and reduces the stresses of group living. It promotes the greater good, generating shared mirth, levity, and joy. Good stories are a powerful tool for making sense of life's challenges and stresses. To the extent that our stories have narrative coherence and encourage others, Keltner (2007:96) says, we empower them to similar ends. These stories, Keltner refers to, have the purpose of uniting people.

Keltner's (2007) purpose with the story telling is to unite whenever you talk. Words have power. The tongue of humankind can be a restless evil with deadly poison (James 3:8). Proverbs 12:18 warns that reckless words pierce like a sword, but that the tongue of the wise brings healing. Paul exhorts us in Ephesians 4:29: "Do not let any unwholesome talk come out of your mouths, but only what is helpful for building others up according to their needs, that it may benefit those who listen." Jesus said in Matthew 12:34 that out of the overflow of the heart, the mouth speaks. If God is recognised as the ultimate power in our lives, He will flow from our hearts even when we speak, and our words will unite people. Ephesians 4:2-3 exhorts us to make every effort to keep the unity of the Spirit.

\section{Conclusion}

Being spiritually intelligent does not guarantee good behaviour. Being a member of a religion does not guarantee good behaviour either. This is true. Being a member of a religion can imply that the person only partakes in religious activities. It does not necessarily mean that the member allows this religion to change his or her way of life. Morgan \& Lawton (2007:xvi) say that there are often gaps between theory and practice. But being a member of a religion, at least implies that the person acknowledges the existence of their god. One must keep in mind that becoming religious is a gradual process. Morgan and Lawton (2007:xv) say that religion is gradually absorbed as it becomes something with which people feel "at home" with and towards which they grow into having loyalty and affection. 
In this article it was not the author's purpose to defend a particular religion. The purpose was to persuade people that religion has a major role to play in creating awareness of a power beyond humankind and to teach everyone that good behaviour flows out of this awareness. Being a member of one religion rather than another is often a matter of people's country of birth, their cultural background, and their particular family (see Morgan \& Lawton, 2007:xv). The fact is we live in a sick world where power abuse kills us, and spiritual intelligence is the way to save the world from the power paradox Keltner (2007) taught us about. Religion has a major role to play in making people aware of the existence of God and highlighting the importance of living a life to please God. It was shown how Christianity can play a role in developing a person's spiritual intelligence and limiting power abuse as the principles for enduring power are typically the "fruits of the Spirit" - the resulting behaviour of a Christian.

\section{Bibliography}

Buzan, T 2001. The power of spiritual intelligence. 10 ways to tap into your spiritual genius. London: Thorsons.

Cole, WO (ed.) 1991. Moral issues in six religions. Oxford: Heinemann Educational.

Cornelius, EM 2014. "The relevance of Galatians 5:16-26 in the modern "spiritual intelligence" debate", NGTT 55 no. 3-4 (2014): 589-610.

J. N. Figgis and R. V. Laurence (eds.), Historical Essays and Studies. London: Macmillan, 1907.

Keltner, D 1 December 2007. “The power paradox. Greater Good Magazine”, [Online]. Available: https://greatergood.berkeley.edu/ article/item/power_paradox [Accessed: 7 June 2019].

Keltner, D 2016 The power paradox. How we gain and lose influence. UK: Penguin Random House.

Keltner, D 016. "Why leaders must give away power in order to keep influence". [Online]. Available: fortune.com/2016/05/18/powerparadox-influence/ [Accessed: 7 June 2019]. 
Martin, JE \& Carlson, CR 1988. "Spiritual dimensions of health psychology”. In WR Miller \& JE Martin (eds.), Behaviour therapy and religion: Integrating spiritual and behavioural approaches to change. Newbury Park, California: Sage. 57-110.

McConnell, AR 25 2010. "Giving really is better than receiving", Psychology Today. [Online]. Available: https://www.psychologytoday. com/us/blog/the-social-self/201012/giving-really-is-better-receiving [Accessed: 22 September 2019].

Morgan, P \& Lawton, CA (eds.) 2007. Ethical issues in six religious traditions, Second edition. Edinburgh: Edinburgh University Press.

Morin, A 2015. "7 Scientifically proven benefits of gratitude", Psychology Today. [Online]. Available: https://www.psychologytoday.com/us/ blog/what-mentally-strong-people-dont-do/201504/7-scientificallyproven-benefits-gratitude [Accessed: 22 September 2019].

Robertson, I 2012. The winner effect: how power affects your brain. London: Bloomsbury Publishing.

Thomas Aquinas 1947. The Summa Theologica. Cincinnati, Ohio:

Benziger Bros. Translated by Fathers of the English Dominican Province, [Online]. Available: https://dhspriory.org/thomas/summa/ FP.html\#TOC04 [Accessed: 20 September 2019]. 